\title{
Prevalence of orofacial pain in wind instrument players
}

\author{
Prevalência de dor orofacial em músicos de instrumento de sopro
}

Giovana Emanuelle Leonardi ${ }^{1}$, Bruna Luiza Kieling ${ }^{1}$, Giselle Emilãine da Silva Reis ${ }^{1}$, Bruno Brandalise Leonardi ${ }^{2}$, Priscila Brenner Hilgenberg Sydney ${ }^{1}$, Daniel Bonotto ${ }^{1}$

DOI 10.5935/2595-0118.20200011

\section{ABSTRACT}

BACKGROUND AND OBJECTIVES: This cross-sectional observational study was conducted due to the uncertainties that still exist about the role of playing wind instruments in musculoskeletal complaints. Therefore, the objective was to assess the prevalence of temporomandibular dysfunction and associated factors in wind instrument players.

METHODS: Wind instrument players from the School of $\mathrm{Mu}-$ sic of Fine Arts of Paraná were evaluated for nine-months. Axes I and II of the Research Diagnostic Criteria for Temporomandibular Disorders was used to obtain the variables of interest. The statistical analyses were performed using the SPSS 2.0 software, using the Fishers Exact test, with a significance level of 5\%.

RESULTS: Thirty-five musicians were examined, $85.7 \%$ were male, and $14.3 \%$ were female. The temporomandibular dysfunction prevalence was $51.4 \%$ being more commonly found in the group II (disc displacements) 34.2\%. This result was statistically meaningful when associated with females $(\mathrm{p}=0,052)$. Group I disorders (muscle disorders) were diagnosed in 5 patients $(14.2 \%)$ and group III disorders (joint disorders) were diagnosed in 3 patients $(8.5 \%)$. Gender also influenced the presence of chronic pain, being more frequent in females $(\mathrm{p}=0.019)$.

CONCLUSION: In this research, we found a high prevalence of individuals affected by temporomandibular dysfunction. Therefore, studies with expanded samples are necessary, as well as educational and preventive measures. Temporomandibular dysfunction specialists should devote more attention to this group of people. Keywords: Chronic pain, Facial pain, Occupational diseases, Syndrome of temporomandibular joint dysfunction.

Giovana Emanuelle Leonardi - Dhttps://orcid.org/0000-0003-0273-3016;

Bruna Luiza Kieling - (Dhttps://orcid.org/0000-0003-1073-0288;

Giselle Emilāine da Silva Reis - Dhttps://orcid.org/0000-0001-8405-4062;

Bruno Brandalise Leonardi - Dhttps://orcid.org/0000-0002-2133-6625;

Priscila Brenner Hilgenberg Sydney - (Dhttps://orcid.org/0000-0003-4612-3439;

Daniel Bonotto - Dhttps://orcid.org/0000-0001-5422-3216.

1. Universidade Federal do Paraná, Departamento de Dentística Restauradora, Disciplina de Dor e Disfunçấo Temporomandibular, Curitiba, PR, Brasil.

2. Escola de Música, Belas Artes do Paraná, Curitiba, PR, Brasil.

Submitted on September 23, 2019.

Accepted for publication on December 11, 2019.

Conflict of interests: none - Sponsoring sources: none.

Correspondence to:

Avenida Prefeito Lothário Meissner, 632 - Jardim Botânico

80210-170 Curitiba, PR, Brasil.

E-mail: giselleesreis@gmail.com

(C) Sociedade Brasileira para o Estudo da Dor

\section{RESUMO}

JUSTIFICATIVA E OBJETIVOS: Estudo observacional transversal foi conduzido devido às incertezas que ainda existem sobre o papel de tocar instrumentos musicais de sopro nas queixas musculoesqueléticas. Portanto, o objetivo foi avaliar a prevalência de disfunção temporomandibular e fatores associados em músicos de instrumento de sopro.

MÉTODOS: Foram avaliados músicos de instrumento de sopro da Escola de Música Belas Artes do Paraná, durante o período de nove meses. Para obtenção das variáveis de interesse, os eixos I e II do instrumento Research Diagnostic Criteria for Temporomandibular Disorders foi utilizado. As análises estatísticas foram realizadas com o software SPSS 2.0, utilizando-se o teste Exato de Fisher, com nível de significância 5\%.

RESULTADOS: Foram avaliados 35 músicos, 85,7\% do sexo masculino e $14,3 \%$ do sexo feminino. A prevalência de disfunção temporomandibular foi de $51,4 \%$, sendo mais comumente encontrado no grupo II (deslocamentos do disco) 34,2\%. Esse resultado apresentou-se estatisticamente significante quando associado ao sexo feminino $(\mathrm{p}=0,052)$. Distúrbios do grupo I (distúrbios musculares) foram diagnosticados em 5 pacientes (14,2\%) e distúrbios do grupo III (distúrbios articulares) foram diagnosticados em 3 pacientes (8,5\%). O sexo também influenciou na presença de dor crônica, sendo mais frequente no sexo feminino $(\mathrm{p}=0,019)$.

CONCLUSÃO: Nesta pesquisa encontrou-se grande prevalência de indivíduos acometidos por disfunção temporomandibular. Portanto, é necessário o desenvolvimento de estudos com amostras ampliadas, bem como propagar medidas educativas e preventivas, sendo esse um público para o qual o especialista em dor e disfunção temporomandibular deve dedicar maiores cuidados. Descritores: Doenças profissionais, Dor crônica, Dor facial, Síndrome da disfunção da articulação temporomandibular.

\section{INTRODUCTION}

Musculoskeletal pain is a frequent occupational risk in musicians ${ }^{1}$. Playing musical instruments that depend on the masticatory system can create an overload, causing increased tension in the masticatory muscles and temporomandibular joint $(\mathrm{TMJ})^{2,3}$. This tension increase with continuous and frequent stimulation can trigger temporomandibular disorder $(\mathrm{TMD})^{4}$, characterized by pain, during masticatory muscle function, in the preauricular area and/or TMJ, limitation or deviation in the performance of mandibular movements; and presence of TMJ sounds (clicking or crepitus) during the function ${ }^{5}$. 
There is growing interest in studying the relationship of TMD in musicians due to monotonous movements produced as a result of static and repetitive muscle work, and long training periods to which they are exposed. There is evidence that monotonous and repetitive movements combined with long training periods can affect the musculoskeletal structures of musicians, especially in the areas where the greatest muscular effort occurs $^{6}$ and may act as triggering and/or perpetuating factor for $\mathrm{TMD}^{7}$. Added to this is the performance-related anxiety and high-stress levels these professionals are often subjected to, which can exacerbate health problems among musicians, including musculoskeletal disorders ${ }^{8,9}$.

It is unclear whether playing an instrument is directly or in combination with other factors associated with $\mathrm{TMD}^{4}$. This inaccuracy is exacerbated when restricted to the group of wind instrument musicians. Given the uncertainties that still exist about the association of playing this type of instrument in musculoskeletal complaints, this study aimed to investigate the prevalence of TMD in wind instrument musicians at the School of Music and Fine Arts of Paraná and to analyze the association between the presence of TMD with the time of practice and the type of instrument.

\section{METHODS}

An observational cross-sectional study following the principles of the Declaration of Helsinki and the norms for conducting observational studies STROBE ${ }^{10-12}$. Data collection was performed between March and November 2018. Thirty-five wind instrument musicians from the School of Music and Fine Arts of Paraná (UNESPAR), Curitiba, were included. All participants received research-related information that explained the study objectives as well as the benefits and risks to which participants would be exposed. Inclusion criteria were to be a wind instrument musician, to be enrolled at UNESPAR, and to be at least 16 years old. Exclusion criteria were individuals with chronic joint diseases.

The clinical examination was conducted according to the guidelines of the Research Diagnostic Criteria for Temporomandibular Disorders (RDC/TMD) ${ }^{13}$, with the adoption of the validated Portuguese version. This study reported prevalence data of RDC/ TMD axes I and II. TMD signs were assessed by clinical examination by a single examiner (E1) throughout the study, who received prior training by an experienced examiner (E2). The third researcher helped record the data during the examinations.

During the clinical examinations, the participants were kept in chairs in the institution's corridor (UNESPAR), under natural light, so that they were comfortable. Following the diagnostic criteria in the RDC/TMD research were evaluated: mouth opening amplitude, verified with the aid of a caliper; mouth opening pattern; joint noises; palpation of the masseter muscle in the bundles of origin, body, and insertion; temporal muscle palpation in the anterior, middle and posterior bundles and TMJ, lateral and dorsal pole palpation. Articular noises were detected by placing the index fingers on the TMJ during opening, closing, laterality, and protrusion movements. For muscle palpation, approximately $1 \mathrm{kgf}$ and $0.5 \mathrm{kgf}$ digital pressure was applied for joint palpation. Throughout the examination, the subject's head was firmly supported passively by the operator's hand. Before muscle and joint palpation, each participant was instructed to express the painful sensation as clearly as possible, if it existed. The instrument used classified pain at palpation in each of the muscle/joint areas as mild, moderate or severe, and assigned a score from 1 to 3 for the level of pain. An anamnestic record was prepared by the research team to obtain information about which wind instrument was used by the study participant, frequency and duration of the trials, the existence of breaks during training, exercises to relax the facial muscles after the practices.

Patients were diagnosed under one or more of the following conditions: muscle disorders (group I), disc displacement (group II), joint disorders (group III). Variables related to axis II of the $\mathrm{RDC} / \mathrm{TMD}$ instrument that assess the presence of chronic pain, degree of disability, depression, and specific and nonspecific physical symptoms were also used. Patients diagnosed with a disorder and with pain complaints were referred to receive care at the Pain and TMD outpatient clinic of the Federal University of Paraná (UFPR).

The Research Ethics Committee of UFPR evaluated and approved this study under opinion CAAE 91294818.3.0000.0102.

\section{Statistical analysis}

Descriptive and inferential statistical analysis was performed using the SPSS 2.0 software using Fisher's exact association test. All inferential analyzes considered a significance level when $\mathrm{p} \leq 0.05$.

\section{RESULTS}

Data were collected from 35 participants, $85.7 \%$ male, and $14.3 \%$ female (Figure 1). The average age of the participants was 27 years, ranging from 17 to 54 years old, distributed as follows: adolescents aged 16 to 19 years (25.7\%), young adults aged 20 to 24 years old $(22.9 \%)$, adults aged 25 to 59 years old $(51.4 \%)$ and older people aged 60 and over (0\%).

It was observed that $51.4 \%$ of the sample had at least one of the TMD diagnoses, distributed as follows: group I, muscle disorders, diagnosed in 5 patients (14.2\%), group II disorders, disc displacements, diagnosed in 12 patients (34.2\%), group III disorders, articular, diagnosed in 3 patients (8.5\%) (Figure 2).

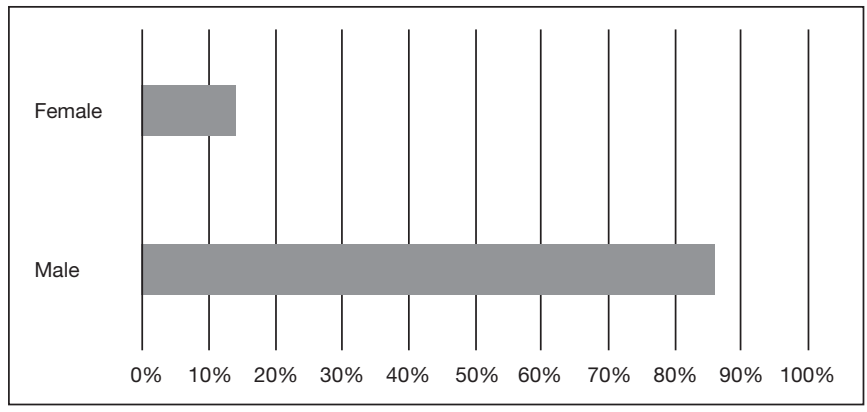

Figure 1. Distribution of the studied sample according to gender 


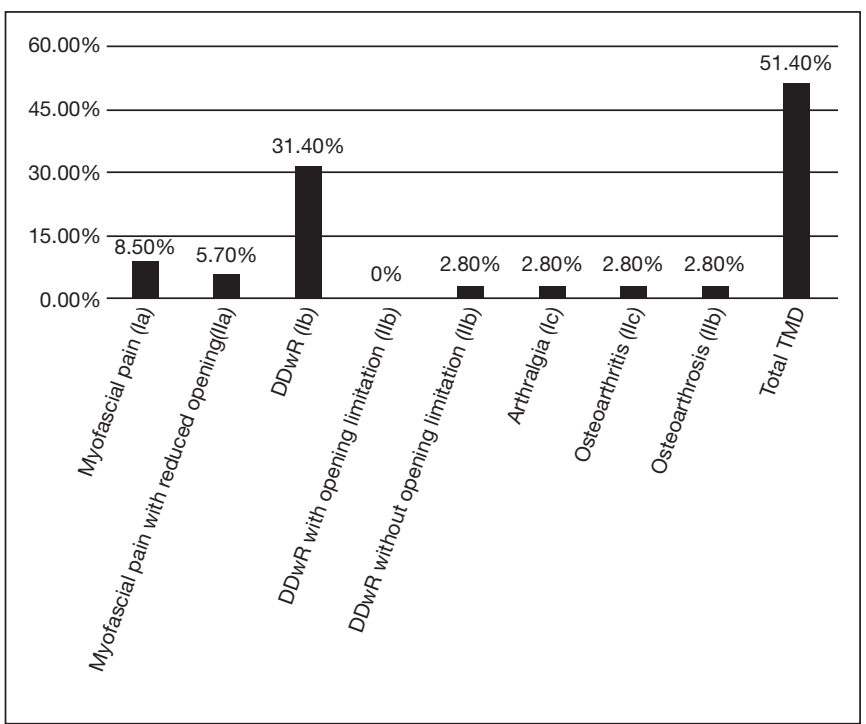

Figure 2. Sample distribution according to each diagnosis of temporomandibular dysfunction

$\mathrm{TMD}=$ temporomandibular disorder; $\mathrm{DDwR}=$ disc displacement with reduction; $\mathrm{DDwoR}=$ disc displacement without reduction.

Table 1. Prevalence of temporomandibular disorders in different groups according to gender

\begin{tabular}{lccccc}
\hline Diagnoses & \multicolumn{2}{c}{ Female } & \multicolumn{2}{c}{ Male } & p-value \\
& Yes & No & Yes & No & \\
\hline Group I & 1 & 4 & 4 & 26 & $0.561^{*}$ \\
Group II & 4 & 1 & 9 & 21 & $0.052^{*}$ \\
Group III & 0 & 5 & 3 & 27 & $0.620^{*}$ \\
Any TMD & 4 & 1 & 14 & 16 & $0.338^{*}$ \\
diagnosis & & & & &
\end{tabular}

Group I = muscle disorders; Group II = disc displacement; Group III = joint disorders. * Fisher's Exact test with significance level of 0.05 . Bold value means statistical significance.
There was no significant difference in the prevalence of TMD between the different age groups, as age did not influence the occurrence of specific symptoms such as crackling, crepitus, teeth grinding, tired jaw sensation, tinnitus, a sensation of bite alteration, $\mathrm{p}=1)$, chronic pain $(\mathrm{p}=0.156)$ and depression $(\mathrm{p}=0.280)$.

Gender differences were found in the prevalence of diagnosis for group II, disc displacements, and this diagnosis was significantly more prevalent in females $(\mathrm{p}=0.052)$ (Table 1). Gender also influenced the presence of chronic pain, being more frequent in females $(p=0.019)$; however, this study found no association between gender and the presence of depression.

The number of years the individual plays wind instruments did not influence the presence of TMD (Table 2). The number of hours of daily practice did not influence the presence of TMD, chronic pain, specific symptoms, and depression. Sixty-two percent of study participants reported regular practice of the wind instrument, while only $37.1 \%$ of them reported performing relaxation exercises during the practice; $51.4 \%$ mentioned warming up and $74.3 \%$ of them reported taking breaks between practices, however, none of these habits influenced the prevalence of TMD. The type of instrument also did not influence the presence of the disease (Table 3).

\section{DISCUSSION}

The prevalence of TMD in the general population is approximately $22 \%{ }^{14}$, with $51.4 \%$ of the sample affected with at least one of the TMD diagnoses. Other studies support the evidence that being a wind instrument musician is associated with a higher prevalence of TMD signs and symptoms. A previous study with these individuals, using the same diagnostic method, found a prevalence of $68.3 \%$ of participants with some type of $\mathrm{TMD}^{15}$.

Table 2. Prevalence of temporomandibular dysfunction in different groups according to the musical practice time of the study participants

\begin{tabular}{lccccccccc}
\hline Diagnoses & \multicolumn{2}{c}{$\leq 3$ years old } & \multicolumn{2}{c}{$3-6$ years old } & \multicolumn{2}{c}{$6-9$ years old } & \multicolumn{2}{c}{$\geq 10$ years old } & \multicolumn{2}{c}{$p$-value } \\
& Yes & No & Yes & No & Yes & No & Yes & No \\
\hline Group I & 0 & 7 & 1 & 4 & 1 & 4 & 3 & 13 \\
Group II & 3 & 4 & 3 & 2 & 1 & 4 & 5 & 11 & $0.746^{\star}$ \\
Group III & 1 & 6 & 1 & 4 & 0 & 5 & 1 & 15 & $0.626^{\star}$ \\
Any TMD Diagnosis & 4 & 3 & 3 & 2 & 1 & 4 & 9 & 7 & $0.599^{\star}$
\end{tabular}

Group I = muscle disorders; Group II = disc displacement; Group III = joint disorders. $\leq=$ less than or equal; $\geq=$ greater than or equal. ${ }^{*}$ Fisher Exact test with significance level of 0.05 .

Table 3. Prevalence of temporomandibular dysfunction in the different groups according to the musical instrument used by the study participants

\begin{tabular}{|c|c|c|c|c|c|c|c|}
\hline \multirow[t]{2}{*}{ Diagnoses } & \multicolumn{2}{|c|}{$\begin{array}{l}\text { Cup-shaped } \\
\text { mouthpiece }\end{array}$} & \multicolumn{2}{|c|}{$\begin{array}{l}\text { Simple edge } \\
\text { instrument }\end{array}$} & \multicolumn{2}{|c|}{$\begin{array}{l}\text { Simple reed } \\
\text { instrument }\end{array}$} & \multirow[t]{2}{*}{$p$-value } \\
\hline & Yes & No & Yes & No & Yes & No & \\
\hline Group I & 2 & 21 & 1 & 4 & 2 & 4 & $0.351^{*}$ \\
\hline Group II & 6 & 17 & 4 & 1 & 2 & 4 & $0.061^{*}$ \\
\hline Group III & 2 & 21 & 1 & 4 & 0 & 6 & $0.497^{\star}$ \\
\hline Any TMD Diagnosis & 9 & 14 & 4 & 1 & 4 & 2 & $0.185^{\star}$ \\
\hline
\end{tabular}

Group I = muscle disorders; Group II = disc displacement; Group III = joint disorders. Cup-shaped mouthpiece = trombone, stick trombone, bass trombone, tuba and trumpet; simple edge instrument = flute, transverse flute; simple reed instrument = clarinet and saxophone. ${ }^{*}$ Fisher Exact test with significance level of 0.05 . 
A research that investigated the association between being a musician and having shoulder, neck and head pain, or having TMD symptoms, found results that support the association between the presence of TMD and the practice of woodwind instruments ${ }^{16}$. When comparing the prevalence obtained in this study with prevalence in other risk groups, such as high impact athletes, a study with professional of mixed martial arts showed that $61 \%$ of them had some type of TMD, while the prevalence among athletes of the Brazilian karate team was $54 \%{ }^{17}$. One of the characteristics that these groups have in common is their frequent exposure to competition anxiety and stress. Future studies should investigate the real effect of this variable.

In this study, the most frequent diagnosis was found in group II, disc displacements (37.1\%). The subgroup with the highest percentage of individuals affected was the disc displacement with reduction (DDwR) (28.5\%). The diagnosis of DDwR without opening limitation was found in $(2.8 \%)$ and no individuals with disc displacement without reduction (DDwoR) with opening limitations were identified. These results are similar to the findings of the research conducted with music students at the Professional School of Arts of Beira Interior, in which $68.3 \%$ of the individuals had some joint disease, $31.7 \%$ were diagnosed with disc anteposition with reduction and $14.6 \%$ diagnosed with disc anteposition without reduction, without opening limitation. In both studies, there were no musicians with no disc anteposition without reduction with opening limitation. As in both studies, the participants were in full musical activity; neither was in the acute phase of the injury, which would probably make the practice of music impossible and, consequently, would not be this individual in the environment in which the research was conducted ${ }^{15}$.

When the relationship between the type of instrument used and the diagnoses was analyzed, there was a tendency for significance with group II diagnoses $(\mathrm{p}=0.061)$ and the use of metal instruments, namely: tuba (23.5\%), trombone (14.7\%), euphonium (5.8\%), trumpet (17.6\%) and French horn (5.8\%), instruments in which sound is produced by direct vibration of the performer's lips over a mouthpiece. The need to apply forces to the stomatognathic system repetitively generates continuous mechanical stress, capable of producing microtrauma. The results found in this study are in line with previous research that quantified the strength in the perioral structures involved during the wind instrument's embouchure mechanism and concluded that metal players apply higher forces than woo$\mathrm{d}$-based musicians, the trombone being the one that requires greater application of force ${ }^{18}$. Also, in a study involving 150 wind instrumentalist musicians, in which imaging studies were performed using lateral cephalometric radiographs and cephalometric analysis, concluded that when the musician uses the tuba and trombone, the mandible moves from a resting position up and back repeatedly, favoring posterior displacement of the mandible condyle and increasing the likelihood of anterior dislocation of the articular disc ${ }^{19}$.

Regarding the association found between gender and diagnosis for group II ( $\mathrm{p}=0.052)$, it is known that the prevalence of TMD is higher in women, with a proportion of five women for each man being reported $(5: 1)^{20}$. One study suggests that women tend to have repositioned mandibular condyles when compared to men, which probably predisposes them to anterior disc displacements ${ }^{21}$. In this study, gender influenced the presence of chronic pain, being more frequent in females $(\mathrm{p}=0.019)$. However, this result should be interpreted with caution because the sample was primarily male, with only five women participating in the study, and two had pain. No association was found between gender and depression. It is unclear whether chronic pain predates depression or the other way around. The idea recently advocated would be a simultaneous coexistence of these two diseases, and depression is an element directly associated with the degree of disability generated by pain $^{22}$. The results obtained in this study regarding gender should be interpreted with caution due to the small number of women included.

In this study, no significant associations were found in the prevalence of TMD among age groups, as well as the number of years of instrumental practice and the number of hours of daily training that did not influence the presence of TMD, chronic pain, specific symptoms and depression. However, a previous study found that the older the musician and the longer the practice, the higher the prevalence of joint $\mathrm{TMD}^{15}$. And this is due to the fact that effects of music practice are accumulated, which can trigger or aggravate a pre-existing $\mathrm{TMD}^{15}$. In addition, the number of hours, the presence of breaks, relaxation exercises and the instrument embouchure were analyzed. None of these factors influenced the presence of TMD, even though there are controversies in the literature, in which years of practice, age and number of hours are the main predisposing factors for the presence of dysfunction ${ }^{23}$. Possibly this association was not found due to the sample size and the individual characteristics of the participants.

The main limitations of this study were sample size and heterogeneity of gender distribution, so results should be interpreted with caution. However, it is important to note that a validated instrument was used for data acquisition and, in conjunction with the current literature, provides evidence that wind instrument musicians have a high prevalence of TMD.

\section{CONCLUSION}

Studies with a higher level of evidence should be developed in this population so that the real impact of using wind instruments on the development and maintenance of TMD can be elucidated, and specific prevention measures can be developed.

\section{REFERENCES}

1. Leaver R, Harris EC, Palmer KT. Musculoskeletal pain in elite professional musicians from British symphony orchestras. Occup Med. 2011; 61(8):549-55.

2. Zimmers PL, Gobetti JP. Head and neck lesions commonly found in musicians. J Am Dent Assoc. 1994;125(11):1487-90, 1492-4, 1496.

3. Steinmetz A, Zeh A, Delank KS, Peroz I. Symptoms of craniomandibular dysfunction in professional orchestra musicians. Occup Med. 2014;64(1):17-22.

4. Attallah MM, Visscher CM, van Selms MK, Lobbezoo F. Is there an association between temporomandibular disorders and playing a musical instrument? A review of literature. J Oral Rehabil. 2014;41(7):532-41.

5. Gauer RL, Semidey MJ. Diagnosis and treatment of temporomandibular disorders. Am Fam Physician. 2015;91(6):378-86. 
6. Baadjou VA, Roussel NA, Verbunt JA, Smeets RJ, de Bie RA. Systematic review: risk factors for musculoskeletal disorders in musicians. Occup Med. 2016; [Epub ahead of print].

7. Van Selms MKA, Ahlberg J, Lobbezoo F, Visscher CM. Evidence-based review on temporomandibular disorders among musicians. Occup Med. 2017;67(5):336-43.

8. Nedelcut $S$, Leucuta DC, Dumitrascu DL. Lifestyle and psychosocial factors in musicians. Clujul Med. 2018;91(3):312-6.

9. Jacukowicz A. Psychosocial work aspects, stress and musculoskeletal pain among musicians. A systematic review in search of correlates and predictors of playing-related pain. Work. 2016;54(3): 657-68.

10. Vandenbroucke JP, Von Elm E, Altman DG, Gotzsche PC, Mulrow CD, Pocock SJ, et al. Strengthening the reporting of observational studies in epidemiology (STROBE): explanation and elaboration. PLoS Med. 2007;4(10):e297.

11. Vandenbroucke JP, Von Elm E, Altman DG, Gotzsche PC, Mulrow CD, Pocock SJ, et al. Strengthening the reporting of observational studies in epidemiology (STROBE): explanation and elaboration. Epidemiology. 2007;18(6):805-35.

12. Vandenbroucke JP, Von Elm E, Altman DG, Gotzsche PC, Mulrow CD, Pocock SJ, et al. Strengthening the reporting of observational studies in epidemiology (STROBE): explanation and elaboration. Ann Intern Med. 2007;147(8):163W-94.

13. Dworkin SF, LeResche L. Research diagnostic criteria for temporomandibular disorders: review, criteria, examinations and specifications, critique. J Craniomandib Disord. 1992;6(4):301-55.

14. Carrara SV, Conti PCR, Stuginski Barbosa J. Termo do $1^{\circ}$ Consenso em Disfunçâo Temporomandibular e Dor Orofacial. Dental Press J Orthod. 2010;15 (3):114-20.

15. Lacerda F, Barbosa C, Pereira S, Manso MC. Estudo de prevalência das disfunçóes temporomandibulares articulares em estudantes de instrumentos de sopro. Rev Port
Estomatol Med Dent Cir Maxilofac. 2015;56(1):25-33.

16. van Selms MKA, Wiegers JW, van der Meer HA, Ahlberg J, Lobbezoo F, Visscher $\mathrm{CM}$. Temporomandibular disorders, pain in the neck and shoulder area, and headache among musicians. J Oral Rehabil. 2019. [Epub ahead of print].

17. Bonotto D, Namba EL, Veiga DM, Wandembruck F, Mussi F, Afonso Cunali P, et al. Professional karate-do and mixed martial arts fighters present with a high prevalence of temporomandibular disorders. Dental Traumatol. 2016;32(4):281-5.

18. Clemente MP, Moreira A, Mendes J, Ferreira AP, Amarante JM. Wind instrumentalist embouchure and the applled forces on the perioral structures. Open Dentistry J. 2019;13(2):107-14

19. Stechman Neto J, Almeida C, Bradasch ER, Corteletti LC, Silvério KC, Pontes MM. Ocorrência de sinais e sintomas de disfunção temporomandibular em músicos. Rev Soc Bras Fonoaudiol. 2009;14(3):362-6.

20. Pinto RG, Leite WM, Sampaio LS, Sanchez MO. Association between temporomandibular signs and symptoms and depression in undergraduate students: descriptive study. Rev Dor. 2017;18(3):217-24.

21. Roach KE, Martinez MR, Anderson N. Musculoskeletal pain in student instrumentalists: a comparison with the general student population. Med Probl Perform Artists. 1994;9(4):125.

22. Schmidt DR, Ferreira VRT, Wagner MF. Disfunção temporomandibular: sintomas de ansiedade, depressão e esquemas iniciais desadaptativos. Temas Psicol. 2015;23(4):973-85.

23. Sayegh Ghoussoub M, Ghoussoub K, Chaaya A, Sleilaty G, Joubrel I, Rifaï K. [Orofacial and hearing specific problems among 340 wind instrumentalists in Lebanon]. J Med Liban. 2008;56(3):159-67. French. 